\title{
$11: 88420838-87881006$
}

National Cancer Institute

\section{Source}

National Cancer Institute. 11:88420838-87881006. NCI Thesaurus. Code C42428.

Physical location of GRM5_Gene 